\section{Time for divine intervention}

SIR-R.J. Berry ${ }^{1}$ reminds us that he and thirteen other professors of science in British universities "gladly accept the virgin birth, the Gospel miracles and the resurrection of Christ as historical events". $\mathrm{He}$ insists, however, that our standards of evidence in approaching apparent miracles should be "just as rigorous" as those we employ for any scientific observation. It is therefore appropriate to note that the virgin birth is documented within the New Testament only in the two nativity stories of Matthew and Luke, and that theologians have long admitted that each is full of its own difficulties, as well as being incompatible with the other. Kümmel says in his standard handbook that they "contradict each other in essential features"

On the Catholic side, R.E. Brown's full-scale study admits that it is "quite impossible" to harmonize them, and that we have "no reliable information about the source of either"3. Mark, the earliest evangelist, introduces Jesus as an adult and records nothing of his early life. Paul, writing still earlier, says that Jesus was "born of a woman" (Galatians 4:4) and this does not suggest acquaintance with the doctrine. Even so conservative a scholar as C.H. Dodd attempted only a halfhearted defence, calling the two infancy narratives a "structure of imagery" with "a basis in fact somewhere behind it all".

As to the resurrection, the gospel narratives contradict each other in essentials, as when one evangelist makes Jesus's appearances to his disciples occur exclusively in Galilee, while another sites them exclusively 80 miles away at Jerusalem. Paul knows nothing of the place of crucifixion, let alone of resurrection. Even the nature of the post-resurrection appearances is not the same in the various accounts. Did Jesus return for a time to normal life with his disciples, or appear only from on high with a body of heavenly radiance? The theologian D.F. Strauss was perfectly justified in saying of the resurrection: "Rarely has an incredible fact been worse attested, and never has a badly attested one been intrinsically less credible". Dodd allowed that "the historian may properly suspend judgement" as to whether "Jesus had in some way left his tomb" . Such concessions have come to be made only because vindicating the actuality of the event on the basis of the New Testament evidence has proved a wellnigh hopeless task.

That such divergent accounts could be written by authors who had already come to believe (for reasons that need to be investigated) that Jesus was virgin-born and rose from the dead is perfectly plausible: that their narratives provide any basis for such belief is not. The events alleged in these stories did not form the basis of the faith, but the stories resulted from faith. One suspects that the professors of science who accept the miracles recorded in these and other gospel stories are less well acquainted with the inadequacy of the documentary evidence than are many of their theological colleagues.

\section{Department of German,}

G.A. Wells

Birkbeck College,

23 Gordon Square,

London WCIH OPD, UK

1. Nature 322, 321 (1986)

. Kümmel, W.G. Introduction to the New Testament (English translation) 43 (SCM, London, 1975)

Brown, R.E. The Birth of the Messiah 7 \& 497 (London, 1977).

Dodd, C.H. The Founder of Christianity, 31 (Collins, Lon don, 1971).

5. Strauss, D.F. Der alte und der neue Glaube, 72 (Leipzig, 1872)

6. Dodd, C.H. The Founder of Christianity, 166-167 (Collins, London, 1971).

SIR-It is hard to disagree with R.J Berry's discussion of the difficulties inherent in the scientific verification or repudiation of "miracles"1, which by their unique nature appear necessarily opaque to the scientific method. Matters of faith aside, even the personal experience of a miraculous event would not meet the standards of scientific publication. It is also difficult to disagree with his comment that "science has limits", as modern philosophers opposed to the demythicization of previous cultures have suggested ${ }^{2,3}$.

Our success as scientists does not compel the belief that science is sufficient to encompass all possible aspects of life, since the scientific method, powerful as it is, is not supplied to us a priori (in which case it would be a "miracle" itself). Certainly such a relativistic attitude need not detract from our ability to perform scientific work

Massachusetts General Hospital

James A. Scott Boston, Massachusetts 02114, USA

1. Berry, R.J. Nature 322, 321 (1986)

2. Hubner, K. Critique of Scientific Reason (University of Chicago Press, 1983).

3. Eliade, M. Ordeal by Labyrinth (University of Chicago Press, 1982).

SIR-On the subject of My Divine Essence, Character, Attributes, Inclinations, Motives, Philosophy, Politics and modus operandi, especially as regards what is vulgarly referred to as miracles, speculations about which have recently been appearing in this magazine, and even more especially as regards My hypothesized role in Universe construction where, so it has been alleged, I, in the form of a bipedal primate outwardly resembling an elderly and bearded male Homo sapiens sapiens, created the Universe for the amusement and edification of men, I should like to state:
(1) I am not a very good Member of the Church of England. (2) When I come to think of it, I am not even a bad Member of the Church of England. (3) When I really pause to consider the matter, I fear (if that is the word) I am not even a Christian, having been around an eternity before that particular creed was organized, and consequently, am Supremely indifferent to its beliefs, dogmas and convictions.

I am, therefore, rather inclined to take a dim view of all people of whatever persuasion voicing opinions on $\mathrm{Me}$, this for the simple reason that, as I am Ineffable and exist beyond all human comprehension in no particular spatio-temporal relation to the physical cosmos, all opinions about $\mathrm{Me}$ are meaningless, when not actually insulting, and, what is worse, tiresomely predictable, especially to One Who knows all things, reflecting as they do only the outlooks and attitudes of these, My unsolicited and intellectually and imaginatively limited interpreters who, if ever they really thought about $\mathrm{Me}$, would be more inclined to keep silent.

You will understand that, while I am not in the habit of presenting My views on theology in the correspondence columns of periodicals (except as occasionally in the past to The Times), I am taking this opportunity to do so because, though as is well attested, My Patience is infinite, It is not that infinite. Nor, may I remind your contributors, does being Omniscient and Omnipotent of neccessity compel One to be All-Benevolent.

I in parting, hope that this correspondence can now be closed. GoD (As revealed to Ralph Estling)

The Old Parsonage, Dowlish Wake,

Ilminster, Somerset TA19 ONY, UK

- God's will be done; this correspondence is now closed. Editor, Nature.

\section{Student loans}

SIR-In response to your leading article entitled "Social security for students" (Nature 321, 797; 1986), I would remind you of a scheme once proposed for the United States by the late Professor Jerrold $R$. Zacharias: that students receive adequate maintenance grants from the central government against a lifelong repayment scheme in the form of a surtax upon their annual income tax. Those who are financially successful would eventually reimburse more (or even much more) than they receive; those who earn less (including ministers, teachers, university lecturers and others in socially valuable but impecunious professions) would be automatically forgiven a part of their grants.

In equilibrium, the surtax should amply finance current grants; the major obstacle is how to finance the starting transient.

1 Rue du Général Gouraud,

BEROL ROBINSON

92910 Meudon, France 